\title{
Study of Performance and Emission Characteristics of Biodiesel Blends of Soybean and Karanja Oil on Twin-Cylinder Diesel Engine Test Rig
}

\author{
Akash K. Ingole ${ }^{*}$, Achuat S. Deo ${ }^{\ddagger}$, Ajay K. Ledade ${ }^{\ddagger}$, Kunal R. Dhote $^{\ddagger}$ and Amol D. Pitale ${ }^{\dagger}$ \\ †Department of Mechanical Engineering, Savitiribai Phule Pune University, MIT College of Engineering, Pune, India \\ ‡Department of Mechanical Engineering, Rashtrasant Tukdoji Maharaj Nagpur University, G.H. Raisoni College of Engineering, Nagpur, India \\ Accepted 03 March 2016, Available online 15 March 2016, Special Issue-4 (March 2016)
}

\begin{abstract}
Today's modern world is facing significant amount of energy crisis regarding conventional fuel. Biodiesel is becoming prominent among the alternatives to conventional petro-diesel due to economic, environmental and social factors. In this study, biodiesel has been produced from Soyabean and Karanj oil by transesterification process. The oil yield of Soyabean and Karanj seed and the biodiesel output of the oil were studied in order to know the productivity of the oil. The physico-chemical properties of the biodiesel like specific gravity, density, flash point, kinematic viscosity (40ㄷ) etc. were evaluated and compared with that of fossil, diesel. The results show minimal difference between physicochemical properties of biodiesel and conventional diesel. This reveals that biodiesel blends can be used as an alternative to conventional diesel. In these blends, two samples were used; each having 10\% and $20 \%$ respectively by volume and the remaining portion was diesel. After the experimentation on the specified diesel engine with prepared blends, EGT, BSFC and BTE for each of the fuel blends are calculated at different loads and compared with diesel fuels. The study further investigates the smoke emission at different loads for all the prepared blends of biodiesel and diesel. For simplification of calculations RPM of engine was kept constant. This shows the performance of the C.I. Engine using biodiesel \& diesel in different approaches \& the use of glycerol which is the by-product of transesterification process is also discussed.
\end{abstract}

Keywords: Biodiesel, alternative fuel, transesterification, physico-chemical properties, blends.

\section{Introduction}

With each passing day, the conventional petroleum fuels are on the verge of extinction. It is believed that the petroleum products and crude oil will be not enough and will be costly. Various researches are going on for the improvement of fuel economy of engines. However as the demand and availability for petrol and diesel is somewhat unbalanced so there is a need to balance since that is mainly happened due to enormous increase in number of vehicles. If the same situation continues then the scenario will be more disastrous and petrol and diesel will be more costly and limited. With increased use and the depletion of fossil fuels, today more emphasis is given on the alternate fuels.

There is an essential need of alternate fuels in a way or other. Today intensive search for the alternative fuels for both spark ignition (SI) and compression ignition (CI) engines and it has been found out that the biomass derived fuels are suited for the alternate fuels. In spark ignition engines fuels like eucalyptus oil and orange oil are the suitable substituent for the petrol. They can be blended with petrol over a wide range of

*Corresponding author: Akash K. Ingole percentage according to the requirement. Similarly in compression ignition engines bio fuels like Jatropha oil, Soybean oil, Karanj oil etc. can be used as substituent fuel for conventional Diesel. These oils can be blended with diesel in different percent by volume ratio. Another reason for the need of alternate fuels for IC engines is the emission problems. Combined with other air polluting factors, the large number of automobiles is a major contributor to the air quality problems of the world. As these fuels cannot be run directly in the engines therefore these are blended with diesel at various percentage. One of the main reasons for selecting these fuels is the similarity in the properties of these with diesel and they are miscible with diesel without any phase separation. The Soybean oil and Karanja oil can be used in CI engine with very little or no modification in engine. Since the cetane number of these oils is close to that of diesel, so it enhances the cetane value of the bio fuel when it is blended with diesel.

M.V.Nagarhalli et al. (2010) carried out experiments to analyze the emission and performance characteristics of a single cylinder $3.67 \mathrm{~kW}$ compression ignition engine fuelled with mineral diesel and diesel-biodiesel blends at an injection 
pressure of 200 bar. The performance parameters evaluated were break thermal efficiency, break specific energy consumption (BSEC) and the emissions measured were carbon monoxide (CO), carbon dioxide $\left(\mathrm{CO}_{2}\right)$, hydrocarbon $(\mathrm{HC})$, and oxides of nitrogen $\left(\mathrm{NO}_{\mathrm{x}}\right)$. The results of experimental investigation with biodiesel blends were compared with that of baseline diesel. The results indicate that the $\mathrm{CO}$ emissions were slightly higher, HC emissions decreased from $12.8 \%$ for $\mathrm{B} 20$ and $2.85 \%$ for $\mathrm{B} 40, \mathrm{NO}_{\mathrm{x}}$ emissions decreased up to $39 \%$ for B20 and $28 \%$ for B40. The efficiency decreased slightly for blends in comparison with diesel. The BSEC was slightly more for B20 and B40. From the investigation it can be concluded that biodiesel can be used as an alternative to diesel in a compression ignition engine without any engine modifications.

V. Sivakumar et al. (2010) experimentally investigated the effects of Methyl-Tetra-Butyl-Ether (MTBE), as an additive, on the performance, combustion and the emission characteristics of a compression ignition (CI) engine. The experimental set-up consists of a diesel engine coupled with an eddy current dynamometer, AVLDi-gas analyzer, AVL smoke meter and a data acquisition system is used. The di-gas analyzer is used to measure $\mathrm{NO}, \mathrm{CO}$ and $\mathrm{HC}$ in the exhaust gases and the smoke meter is used to measure the smoke coefficient of the exhaust gases. The whole investigation is carried in two phases using the neat diesel in the first phase and the MTBE blended diesel fuels in the second phase. The MTBE blended diesel fuels are prepared in the varying proportions of MTBE $(2,4$ and $6 \%)$; subsequently the stability characteristics of the fuels are studied under static conditions. All the experiments are conducted at a constant speed of 1500 RPM by varying the brake load and the data obtained from the experiments are used to evaluate the performance and the combustion characteristics while, the emission characteristics are directly measured. The experimental results revealed that a significant improvement in the performance and appreciable reduction in the emissions for the MTBE blended diesel fuels on compared with neat diesel. The combustion analysis is supported the outcome on the performance and emission of the engine.

Adebayo G.B et al. (2011) carried out the production of biodiesel from the chemically extracted oil of Jatropha carcass has been carried out. The oil yield of Jatropha seed and the biodiesel output of the oil were studied in order to know the productivity of the oil. The physico-chemical properties of the biodiesel produced were evaluated and compared with that of fossil diesel. The physico-chemical properties assessed includes, specific gravity, density, flash point, kinematic viscosity $\left(40^{\circ} \mathrm{C}\right)$, sulphate ash, carbon residue, and iodine value. The results revealed significant differences between the physico-chemical properties of biodiesel from that of fossil diesel.

Aim of this work is to replace diesel with sufficient amount of Soybean and Karanja oils blended with diesel. The use of biodiesel helps to reduce $\mathrm{HC}, \mathrm{CO}$ and particulate matter (smoke density) in the diesel engine exhaust. Biodiesel produced from Soybean and Karanja oils blended with diesel are to be used here. These biodiesels have the properties like higher cetane number, higher viscosity, lower flash point etc. Biodiesel is prepared by the process of Transesterification, which appeared as effective method of using fatty acids in diesel engines. The glycerol obtained as co-product in Transesterification process. This glycerol can be used in chemical industries.

\section{Experimental Setup}

Fig.1 shows the schematic diagram of experimental setup. A single cylinder, four stroke, direct injection, naturally aspirated, air cooled computerized Diesel engine test rig is employed for the present work. The engine is coupled to a rope brake dynamometer, an Opax 2000 II smoke meter and an exhaust gas analyzer. The detailed specification of the engine is given in Table 1.

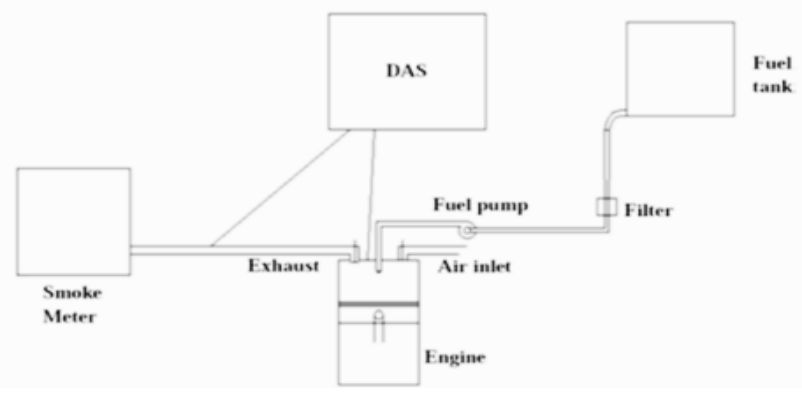

Fig.1 Experimental Setup

\subsection{Preparation of blended diesel}

The Soybean and Karanj oil are blended with diesel with the proportions of $15 \%$ and $20 \%$ by volume using magnetic stirrer.

Table 1 Engine specification

\begin{tabular}{|c|c|c|}
\hline $\begin{array}{l}\text { Sr. } \\
\text { No. }\end{array}$ & Item & Technical Data \\
\hline 1 & Model & KIRLOSKAR, TV-2 \\
\hline 2 & Rated BHP / KW & $16 / 11.8$ \\
\hline 3 & Bore x Stroke (mm) & $87.5 \times 110.0$ \\
\hline 4 & Swept Volume (CC) & 853 \\
\hline 5 & Compression Ratio & $17.5: 1$ \\
\hline 6 & Rated RPM & 1800 \\
\hline 7 & No. of Cylinder & 2 \\
\hline 8 & Governor & $\begin{array}{c}\text { Centrifugal mechanical } \\
\text { type }\end{array}$ \\
\hline 9 & Fuel Tank Capacity (Lts.) & 11 Lts \\
\hline 10 & Method of Cooling & Water \\
\hline 11 & Bearing Type & Bush \\
\hline 12 & Method of Starting & $\begin{array}{c}\text { Cold Starting with the help } \\
\text { of Starting Handle }\end{array}$ \\
\hline 13 & Engine Rotation & $\begin{array}{c}\text { Standard Rotation } \\
\text { Clockwise facing Flywheel }\end{array}$ \\
\hline 14 & $\begin{array}{l}\text { Sp. Fuel Consumption gms } \\
\text { / bhp - hr. }\end{array}$ & 185 \\
\hline 15 & $\begin{array}{l}\text { Sp. Fuel Consumption gms } \\
\text { / Kwhr }\end{array}$ & 251 \\
\hline 16 & Lubrication System & Plunger Pump \\
\hline 17 & Crank Shaft Height (mm) & 203 \\
\hline 18 & Engine Net Weight (kg) & 145 \\
\hline
\end{tabular}


Table 2 Smoke meter specifications

\begin{tabular}{|c|c|}
\hline Opacity meter type & partial sampling \\
\hline Design & $\begin{array}{c}\text { ISO } 3173, \text { EEC 72/CUNA NC } \\
\text { 005/11 }\end{array}$ \\
\hline Light source & $\begin{array}{c}\text { Green LED with peak in } \\
\text { wavelength of 569nm }\end{array}$ \\
\hline $\begin{array}{c}\text { Reference temperature } \\
\text { of smoke chamber }\end{array}$ & $90^{\circ} \mathrm{C}(+/-)$ \\
\hline $\begin{array}{c}\text { Operating ambient } \\
\text { temperature }\end{array}$ & $2-40^{\circ} \mathrm{C}$ \\
\hline Power Supply & $\begin{array}{c}110 / 220 / 240 \text { (factory selected }) \\
\mathrm{Vac}_{\mathrm{ac}}+10 /-15 \% \text { or } 10.5 \text { to } 16 \mathrm{Vdc}\end{array}$ \\
\hline Dimension & $420 * 210^{*} 400$ \\
\hline
\end{tabular}

Table 3 Fuel properties of soybean biodiesel blend

\begin{tabular}{|c|c|c|}
\hline Sample No. & 1 & 2 \\
\hline$\%$ Diesel & 90 & 80 \\
\hline \%Biodiesel & 10 & 20 \\
\hline Cetane no. & 46 & 43 \\
\hline Flash Point $\left({ }^{\circ} \mathrm{C}\right)$ & 92 & 132 \\
\hline Density $\left(\mathrm{kg} / \mathrm{m}^{3}\right)$ & 839.4 & 847.8 \\
\hline $\begin{array}{c}\text { Calorific } \\
\text { Value }(\mathrm{MJ} / \mathrm{kg})\end{array}$ & 41.957 & 39.229 \\
\hline
\end{tabular}

Table 4 Fuel properties of karanj biodiesel blend

\begin{tabular}{|c|c|c|}
\hline Sample No. & 1 & 2 \\
\hline \%Diesel & 90 & 80 \\
\hline \%Biodiesel & 10 & 20 \\
\hline Cetane no. & 45 & 43 \\
\hline Flash Point $\left({ }^{\circ} \mathrm{C}\right)$ & 61 & 132 \\
\hline Density $\left(\mathrm{kg} / \mathrm{m}^{3}\right)$ & 841.4 & 847.8 \\
\hline $\begin{array}{c}\text { Calorific } \\
\text { Value }(\mathrm{MJ} / \mathrm{kg})\end{array}$ & 41.645 & 39229.72 \\
\hline
\end{tabular}

\section{Performance Analysis}

The main objective of the study was to fuel the diesel engine with bio-fuel blends and compare the performance results with baseline data and evaluate the performance of this alternative fuels on internal combustion engine and calculation of energy consumption, power produced, brake specific energy consumption, brake thermal efficiency, in diesel engine.

\subsection{Brake Specific Fuel Consumption}

Figure 4.1 shows the variation of BSFC with Load for different fuels. The effect of load on brake specific fuel consumption between diesel and different blends can be seen in the graph. It is seen that brake specific fuel consumption decreases when the Load is increased for all operations of diesel and biodiesel and their blends. It can be observed that brake specific fuel consumption decreases when blend is used for any given load. The percent decrease in specific fuel consumption was decreased with decreased amount of diesel fuel in the blended fuels. This is mainly due to viscosity and lower heating value. As a result, the fuel consumption to obtain same power is less and leads to better results.

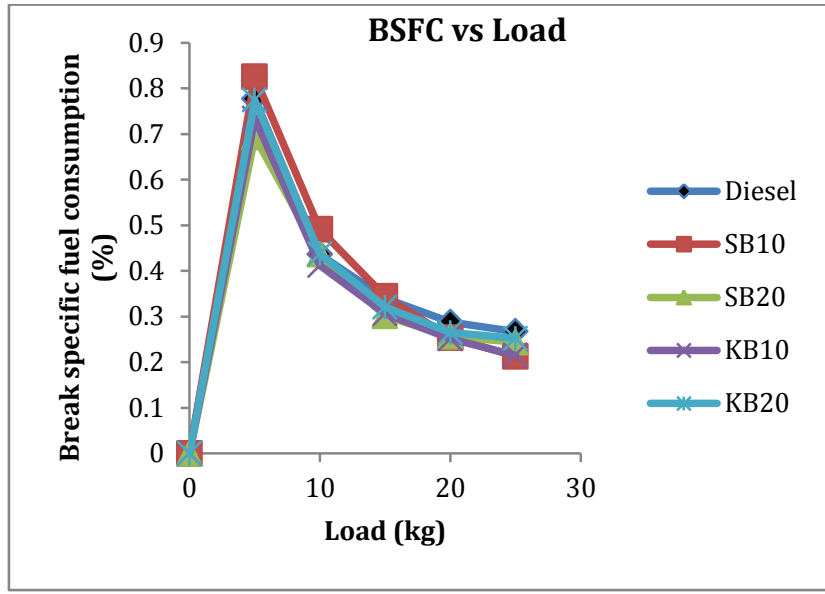

Fig. 2 Comparison of brake specific fuel consumption Vs. Load

\subsection{Brake Thermal Efficiency}

Brake Thermal Efficiency of biodiesel is higher than that of all other fuels due to its lower calorific value. All the blends exhibited higher brake thermal efficiencies than Diesel. This may be caused by the available oxygen content in the blend which improves the combustion process despite the fact that oxygenated fuel has lower heating value. Karanja B20 blend has lower calorific value as compared to all the other blends. This leads to the enhancement of combustion, hence improving efficiency.

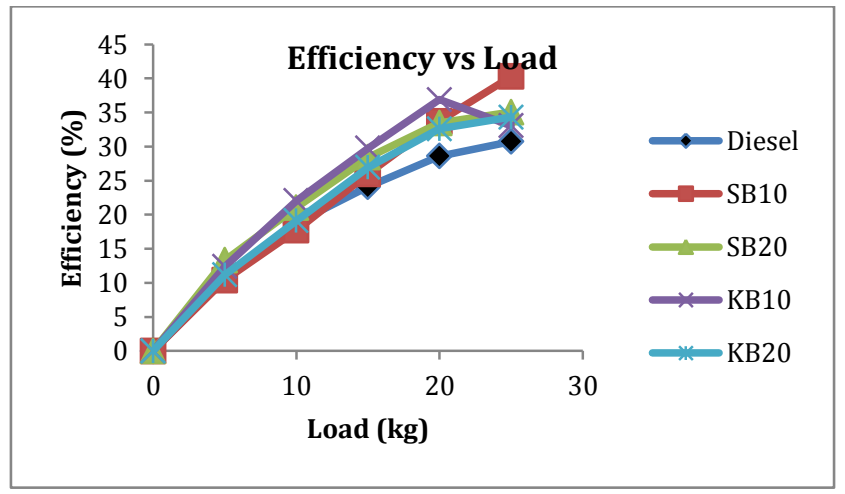

Fig. 3 Comparison of Brake thermal efficiency Vs. Load

\subsection{Exhaust gas temperature}

EGT shows the burning efficiency. The EGT may be high due to the following reasons

a) Complete combustion

b) If the afterburning stages of combustion is longer or engine misfire took place or injection time is not proper.

For complete combustion fuel should be evaporated early as possible as and mixed with air. Ethanol has low viscosity. Biodiesel has lower calorific value. It helps the combustion process. Biodiesel blend has more oxygen content than other blend .It helps for better combustion. It may be one of the reasons for 
high EGT in blends. It can clearly be seen that exhaust gas temperature for different biodiesels is higher than that of diesel. It can also be concluded that exhaust gas temperature increases with increased loads.

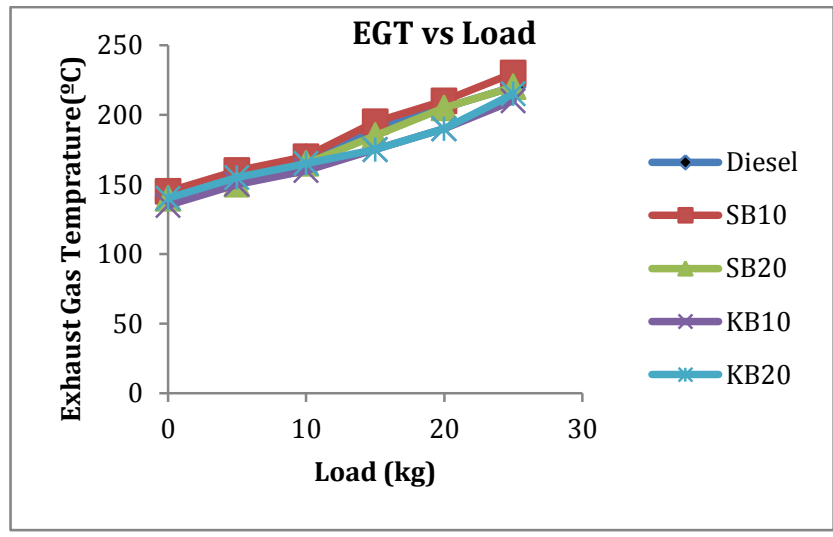

Fig. 4 Comparison of exhaust Gas Temperature vs. Load

\subsection{HC emissions}

HC emissions of diesel are higher than that of all other fuels due to its higher calorific value. All the blends exhibited lower HC emissions than diesel. This may be caused by the available oxygen content and lower calorific value in the blend which improves the combustion process HC emissions are increased with increased values of load. Fig 4.1.4 shows the comparison of $\mathrm{HC}$ emissions of different fuels at different loads.

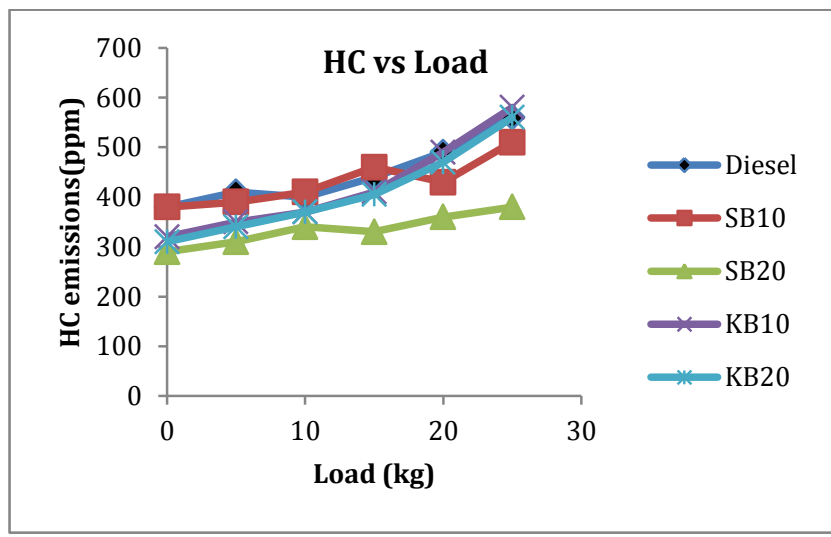

Fig. 5 Comparison of Hydro-carbon emissions Vs. Load

\subsection{Carbon mono-oxide emissions}

CO emissions are caused by burning of fuel. Higher the value of calorific value higher will be the emissions.CO emissions depend on two factors:

a) Combustion Process (Unburned gases)

b) Carbon content in the fuel

Fig.4.1.5 indicates comparison of $\mathrm{CO}$ emissions of different biodiesels with different Loads. Fig describes the lower values of $\mathrm{CO}$ emissions at intermediate loads for all the fuels. It also can be seen that all the biodiesel blends have lower values of $\mathrm{CO}$ emissions than that of Pure Diesel.KaranjaB-20 blend shows lower value of CO emissions than that of karanja B-10 blend. So it can be concluded from the graph that $\mathrm{CO}$ emissions decreases with increased value of Biodiesel percentage.

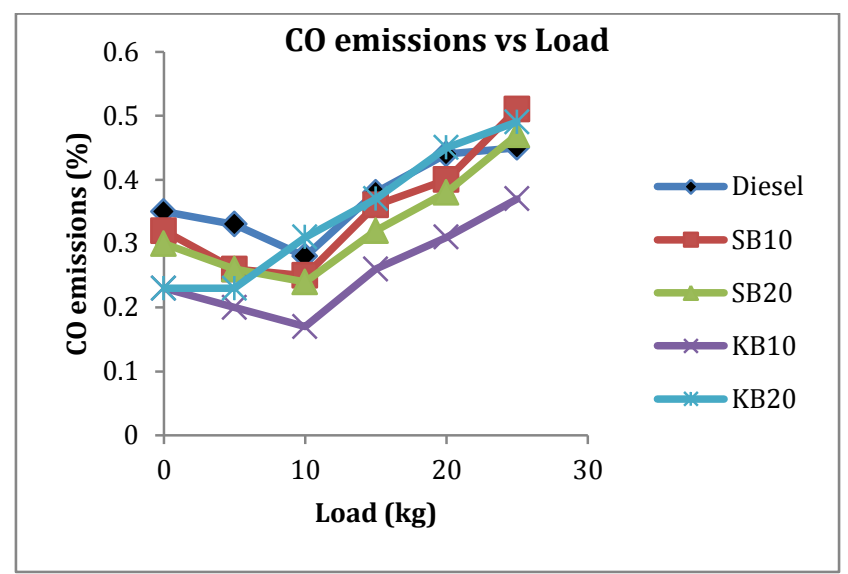

Fig. 6 Comparison of CO emissions Vs. Load

\subsection{Smoke Density}

The smoke opacity increased with the load for diesel fuel and diesel-biodiesel blends. The smoke is formed due to incomplete combustion. It is obvious that the smoke emissions are reduced with biodiesel blends. The smoke opacity reduced with increase of biodiesel percentage in blends. In previous study, it is seen that the smoke emission reduced significantly by the addition of more biodiesel to blends. In this study, results obtained are much similar to previous ones. All the blends have lower values of smoke Opacity than that of diesel. In this study, it can also be seen that smoke density increases at higher loads.

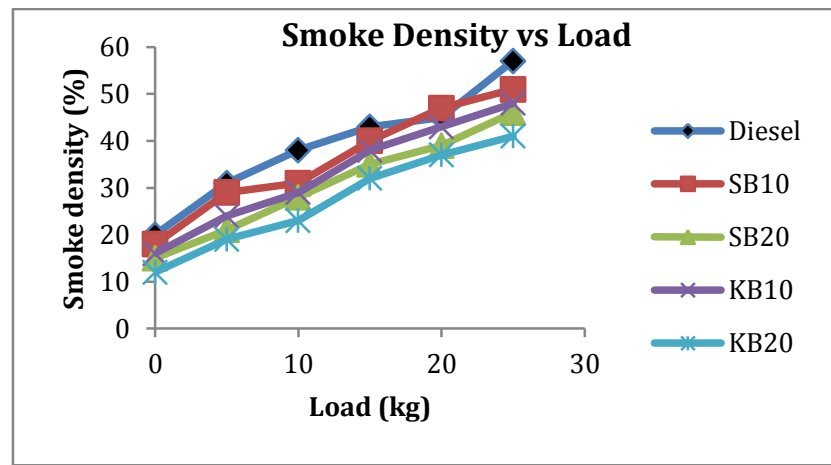

Fig. 7 Comparison of smoke density vs. load

\section{Conclusions}

1) The experimental study of the addition of biodiesel blended diesel fuel in engine gave better engine performance and emissions characteristics. Dieselbiodiesel blends (S10D90, S20D80, K10D90, and K20D80) show better stability and can be used in diesel engine without major modification. 
1. The BSFC of soya and karanja blends is slightly higher at intermediate loads while it is less at higher loads as compared to petro diesel and BTE is slightly lower than that of petro-diesel at lower load while it increases with the increase in load.

2. Soya and karanja oil, having higher oxygen content than diesel fuel, show excellent ability to minimize smoke emissions, especially at high engine load. Karanja is more volatile and oxygen content fuel so its blend (K20D80) showed higher reduction in smoke emission.

3. CO emission is reduced at intermediate load as compared to petro diesel. It is found that CO emission in the K10D90 blend is significantly reduced. It may be because of higher content of oxygen in the karanja oil.

4. HC emissions are reduced as the percentage of biodiesel in blend increases. It is found that K20D80 has lower value of $\mathrm{HC}$ emissions than that of K10D90 and similarly S20D80 has lower HC emissions. It is also noticed that $\mathrm{HC}$ emissions increases with higher loads.

5. Comparison of experimental graphs with the standard graphs gives similar trend with slight advantage over their performances.

From all the result and discussion main conclusion came arise is that Karanja Biodiesel in blend form is better to use in diesel engines. It shows performance closer to that of diesel on the expense of cost little higher. So these fuel blends proved as sustainable, suitable, prominent alternative fuel for all types of diesel engine

\section{References}

Nagarhalli M.V., Nandedkar V.M. and Mohite K.C. (2010) emission and performance characteristics of karanja biodiesel and its blends in a c.i. engine and its economics.

V. Sivakumar, J. Sarangan, R. B. Anand (2010)Performance, Combustion and Emission Characteristics of a CI Engine using MTBE Blended Diesel Fuel, IEEE.

Adebayo G.B, Ameen O.M and Abass L.T (2011) Physicochemical properties of Biodiesel produced from Jatropha Carcass oil and fossil diesel.
Agarwal A. K., J. Bijwe and Das L. M (2003), Effect of biodiesel utilization of wear of vital parts in compression ignition engine, ASME J. Eng. Gas Turbines Power, 125, pp. 604611.

Demirbas Ayhan (2005), Biodiesel production from vegetable oils via catalytic and non-catalytic supercritical methanol transesterification methods, Progress in Energy and Combustion Science, 31, pp. 466-487.

N. Ravi Kumar, Rajesh Guntur, and Y.M.C. Sekhar (2012), Performance and Emission Characteristics of a Slow Speed Diesel Engine Fuelled With Soybean Bio Diesel.International Journal of Emerging Technology and Advanced Engineering, Volume 2, Issue 4.

Ekanath R. Deore, Milind S. Patie (2014), Effect of Blends of Two Kind of Biodiesel on Performance and Emission of Single Cylinder DI Diesel Engine. ICONCE.

Kexin Liu, John P. Wood, Eoghan R. Buchanan, Pete Martin, Victoria E. Sanderson (2010), Biodiesel as an Alternative Fuel in Siemens Dry Low Emissions Combustors: Atmospheric and High Pressure Rig Testing.

I.M. RizwanulFattah, H.H.Masjuki, A.M.Liaquat, RahizarRamli, M.A.Kalam, V.N. Riazuddin (2013), Impact of various biodiesel fuels obtained from edible and non-edible oils on engine exhaust gas and noise emissions Renewable and Sustainable Energy Reviews,18, pp. 552-567.

Mustafa Balat, Havya Balat (2008), A critical review of biodiesel as a vehicular fuel, Energy Conversion and Management, 49, pp. 2727-2741.

Benjamin W. Mercherosch, Christopher J. Polonwski, Scott A Meirs, Jeffrey D. Naber (2010), Combustion and emissions characterization of Soy- Methyl Ester biodiesel blends in an automotive turbocharged diesel engine. ASME, Vol. 132.

Kailas M. Talkit, O.T. Mahajan (2012), Studies of physicchemical properties of Soybean oil and its blend with petroleum oil. International journal of mechanical engineering and technology, volume-3, issued-2.

G. Lakhsmi Narayna Rao, A.S. Ramadhas, N. Nalluswamy, P. Sakthivel (2010), Relationships among the physical properties of biodiesel and engine fuel system design requirement, International Journal of Energy and Environment, pp. 919-926.

Pritee Purohit, Sanjay Gaikwad, Raviraj Gurav (2012), Properties and specifications of biodiesel and their influence on performance of engine: A Review, International Conference On Recent Technology.

LAB Report [Anacon Laboratories] ISO 9001:2008, ISO 18001:2007, Recognized by Ministry of Environment and forests (MoEF), New Delhi. Accredited by Quality Council of India 